\title{
Effects of Streptozotocin-induced Diabetes on Receptive and Proceptive Behaviors in Female Rats
}

\author{
Toru R. SAITO, Isao SERIZAWA**, Ryoji HOKAO***, Atsushi TOHEI****, \\ Shinobu AOKI-KOMORI*, and Kazuaki W. TAKAHASHI \\ Department of Laboratory Animal Science and ${ }^{*}$ Veterinary Medical Teaching Hospital, Nippon \\ Veterinary and Animal Science University, 1-7-1 Kyonan-cho, Musashino-shi, \\ Tokyo 180, **Pharmaceutical Development Laboratory, Kirin Brewery Co., \\ Ltd., 1-2-2 Souja-machi, Maebashi-shi, Gunma 371, and ${ }^{* * *} 1$ st \\ Research Division, Imamichi Institute for Animal Reproduction, \\ 782-8 Shimo-ozutsumi, Dejima-mura, Niihari-gun, \\ Ibaraki 300-01, Japan
}

(Received 22 March 1994/Accepted 31 May 1994)

\begin{abstract}
Sexual dysfunction in diabetic men is thoroughly recognized, while not yet done in diabetic women. Recently, Streptozotocin (STZ)-induced male rats showed a significantly depressed copulatory behavior, compared with normal animals. We investigated whether STZ-induced diabetic female rats would produce observable deficits in sexual behavior. Results in the present study are the first to show that STZ-induced diabetic female rats have a depressed sexual behavior.-KEY WORDS : diabetes, female rats, sexual behavior, streptozotocin
\end{abstract}

It is well known that sexual dysfunction is frequently associated with diabetes in men. In diabetic men, the erection problems are usually attributed to pelvic autonomic neuropathy, although a significant correlation between sex problems and neuropathy does not demonstrate a causal relationship [12]. While some investigators reported an increase in the incidence of sexual dysfunctions in diabetic women compared to normal women $[6,9]$, others did not report such a difference $[4,5,13]$.

Recently, Steger et al. [10] demonstrated that male rats with streptozotocin (STZ)-induced diabetes provide an interesting and relevant model to study the effects of diabetes on male reproduction, since they exhibit several deficits in reproductive function similar to those in diabetic men. Reproductive changes in STZ-treated male rats include decreased gonadotropin titers, and low plasma testoster- one levels $[2,3]$. Nevertheless, a positive association between sexual dysfunction and diabetes in women and female laboratory animals has not been demonstrated.

The purpose of the present study was to determine whether female rats treated with STZ would exhibit severe deficits in sexual function similarly to male rats.

Subject: Twenty-one female rats of the Wistar-Imamichi strain, obtained from Imamichi Institute for Animal Reproduction (Niiharigun, Ibaraki, Japan), were used in this study. The animals were kept in a room with a temperature of $22 \sim 27^{\circ} \mathrm{C}$ and subjected to a lightschedule of $14 \mathrm{hrs}$ light and $10 \mathrm{hrs}$ darkness (lights off at $19: 00)$. They were provided with pellet diet MB-1 (Funabashi Farm Co., Ltd., Chiba, Japan) and water ad libitum. Upon reaching 8 weeks of age, all female rats were ovariectomized under ether anesthesia. Two

**** Present address : Laboratory of Veterinary Physiology, Tokyo University of Agriculture and Technology, 35-8 Saiwai-cho, Fuchu-shi, Tokyo 183, Japan 
weeks later, the females were subcutaneously treated with $2 \mu \mathrm{g}$ estradiol benzoate (EB, dissolved in $0.1 \mathrm{~m} \ell$ sesame oil) daily for 3 days and $0.5 \mathrm{mg}$ progesterone $4 \sim 6 \mathrm{hrs}$ before the behavioral test on the fourth day.

Drug : Streptozotocin (STZ, Sigma Chemical Co., MO, USA) was dissolved in saline acidified to $\mathrm{pH} 4.5$ with citrate and immediately administered intraperitoneal (i. p.) in a volume of $0.1 \mathrm{~m} \ell / 100 \mathrm{~g}$ body weight. Control females were given the same volumes of acidified saline alone.

Sexual behaviors testing : In the behavioral testings, each female was placed in a semicircular observation cage (radius 40 , hight 50 $\mathrm{cm}$ ) with one sexually active male of the same strain. When tests were initiated at $19: 00$ of the dark period, dim red light was provided. The female was observed until she received a total of 10 mounts. The presence of lordosis was recorded after each mount and the results were expressed in terms of the lordosis-tomount $(\mathrm{L} / \mathrm{M})$ ratio and used as an index of sexual receptivity. In addition, the incidence of proceptive behaviors such as ear-wiggling, hopping and darting was also recorded.

Experimental procedure: Three weeks after ovariectomy, the females received a single injection of vehicle or 2 doses of STZ : 50 and $100 \mathrm{mg} / \mathrm{kg}$ body weight. Seven animals for each dose were used. Twenty-four hours after STZ administration, diabetes was verified by glucosuria and blood glucose level $(>180 \mathrm{mg} /$ $\mathrm{d} \ell$ ). Glucosuria and blood glucose were determined semiquantitatively with Tes-Tape (Eli Lilly \& Co., IN, USA) and Glucostix (MilesSankyo Co., Tokyo, Japan), respectively.

Statistical analysis: The $\mathrm{L} / \mathrm{M}$ ratios were analyzed using the Mann-Whitney U test. For comparison of incidence of proceptive behaviors between groups, Fisher's exact probability test was used.

Changes in body weight in STZ-treated and control groups are shown in Fig. 1. In 100 $\mathrm{mg} / \mathrm{kg} \mathrm{STZ}$-treated group, 4 out of 7 animals were dead within $24 \mathrm{hrs}$ after STZ injection. Body weights of remaining 3 animals showed a progressive decrease after STZ injection, and then increased gradually. Thereafter, all 3 animals were dead. During the study body weight gain of $50 \mathrm{mg} / \mathrm{kg} \mathrm{STZ}$-treated group was significantly inhibited after STZ injection, compared with control group $(\mathrm{P}<0.001)$.

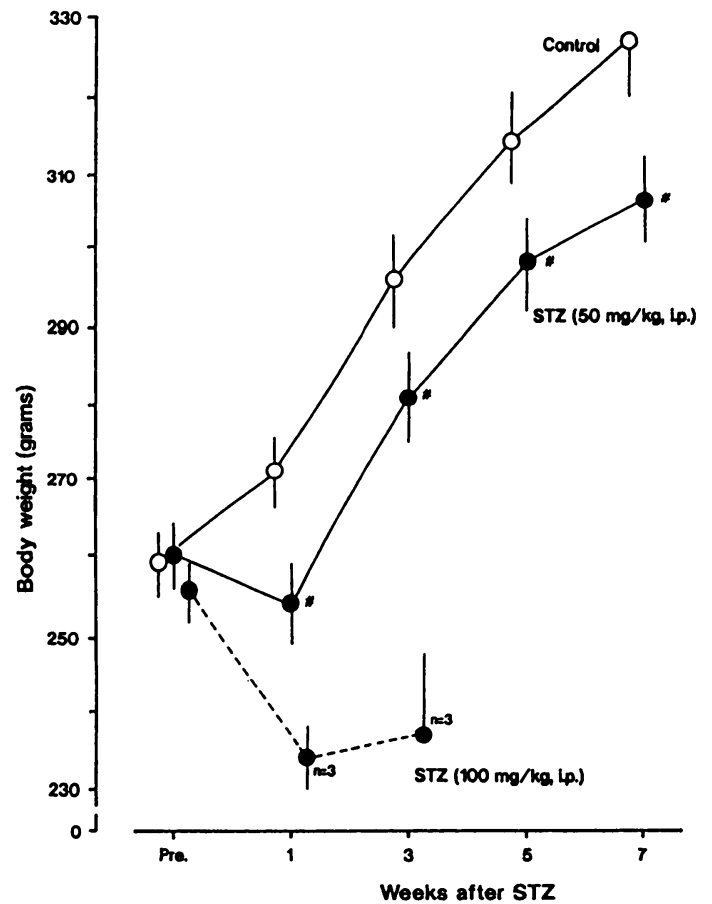

Fig. 1. Body weights of control and streptozotocin (STZ)-induced diabetic rats. Values represent the mean \pm SEM of 7 rats ${ }^{*} \mathrm{P}<0.001$ vs. control

Fig. 2 shows effects of STZ on the $\mathrm{L} / \mathrm{M}$ ratio in female rats. There were no differences in $\mathrm{L} / \mathrm{M}$ ratios among three groups of rats before $\mathrm{STZ}$ injection. The $\mathrm{L} / \mathrm{M}$ ratios in remaining 3 females given $100 \mathrm{mg} / \mathrm{kg}$ STZ showed a remarkable decrease after STZ injection. In $50 \mathrm{mg} / \mathrm{kg} \mathrm{STZ}$-treated group the L/M ratio was similar to that in control group at one week after STZ injection, but showed significantly low values : 0.73 at three, 0.56 at five and 0.59 at seven weeks after STZ injection. During the study the $\mathrm{L} / \mathrm{M}$ ratios in control group were 0.91 to $1.0(\mathrm{P}<0.05$ and 0.01$)$.

Incidences of proceptive behaviors in three groups are shown in Fig. 3. In $50 \mathrm{mg} / \mathrm{kg} \mathrm{STZ-}$ treated group percentages of proceptivity tended to decrease after STZ injection. There were no signficant differences, compared with control. The remaining 3 females in $100 \mathrm{mg} / \mathrm{kg}$ STZ-treated group showed low ratios of 0 to $33.3 \%$ after STZ injection.

In summary, the following can be said about the effect of STZ on the female rat. STZ is a diabetogenic agent commonly used to induce diabetes in a number of animal species. 


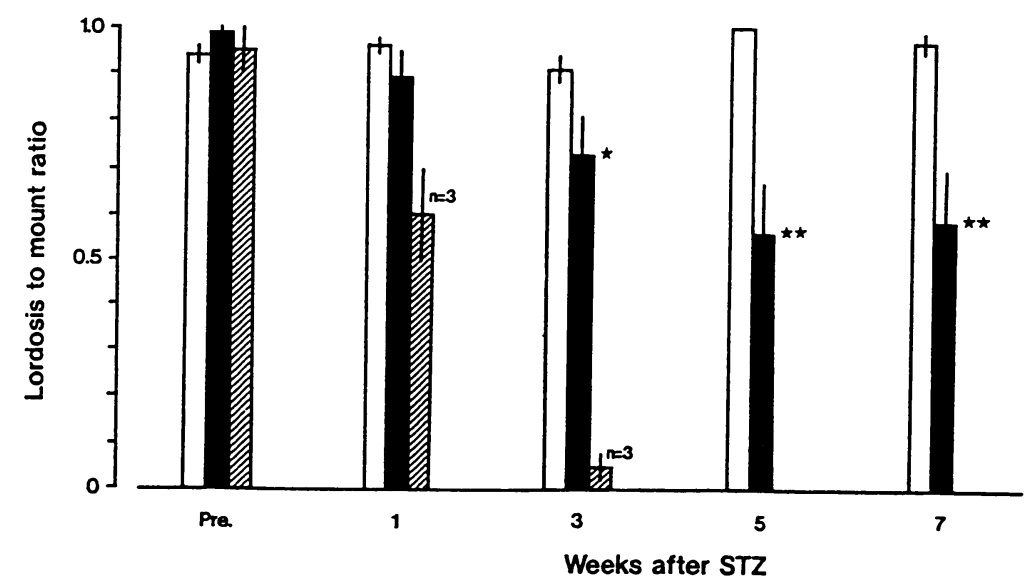

Fig. 2. Mean ( \pm SEM of 7 animals) lordosis quotients in control $(\square)$ and streptozotocin ( $: 50 \quad 100 \mathrm{mg} / \mathrm{kg}$, i. p.) -induced diabetic rats $\star \mathrm{P}<0.05, \star \star \mathrm{P}<0.01$ vs. control

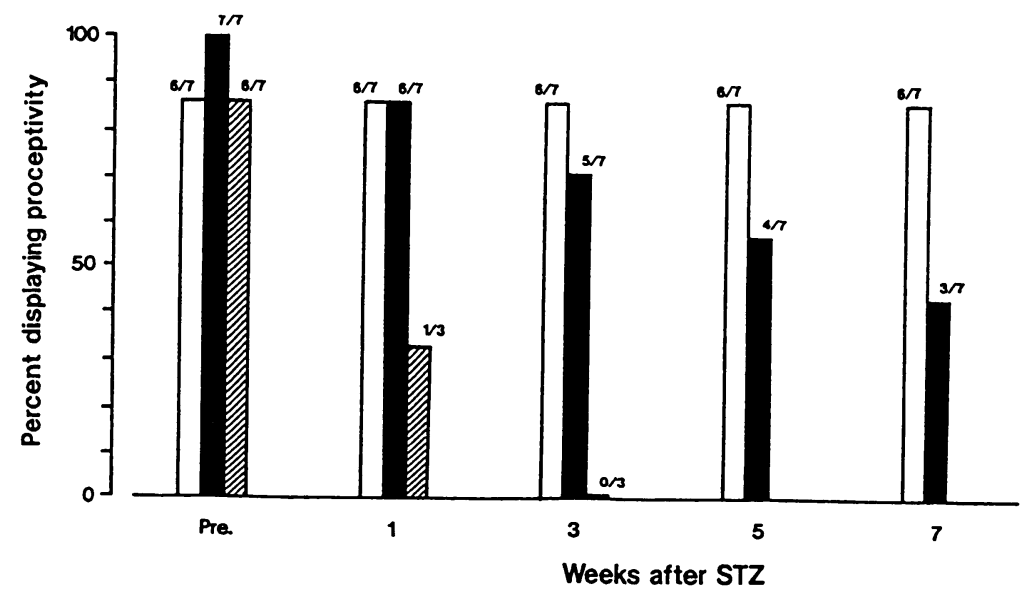

Fig. 3. Percent of control $(\square)$ and streptozotocin $(\square: 50 \quad \mathbb{Z}: 100 \mathrm{mg} / \mathrm{kg}$, i. p.) -induced diabetic rats displaying proceptive behavior

First, our data indicate that all 7 females in 100 $\mathrm{mg} / \mathrm{kg} \mathrm{STZ}$ group were severely diabetic with pronounced body weight loss and death, while all in $50 \mathrm{mg} / \mathrm{kg} \mathrm{STZ}$ group were mildly diabetic with slight body weight gain, glucosuria, and blood glucose $>180 \mathrm{mg} / \mathrm{d} \ell$ throughout experimental period. In control group, all animals had normal body weight gain, no glucosuria, and blood glucose $<70 \mathrm{mg} / \mathrm{d} \ell$. Second, STZinduced diabetic female rats show a lower sexual receptive behavior, compared with control animals. In $100 \mathrm{mg} / \mathrm{kg} \mathrm{STZ}$ group, however, the suppressive receptivity may result from the debility of general condition. Our findings are in agreement with those observed in male rats with STZ by Steger et al. [10]. And finally, no influence on proceptive behavior is observed in STZ - induced diabetic females. Previous studies $[7,8]$ have demonstrated that estrogenprimed ovariectomized female rats treated with LHRH display receptive, but not proceptive behaviors. Dudley et al. [1] has observed a significant reduction in lordosis by administration of LHRH antagonist analogs and an antibody to $\mathrm{LHRH}$. These findings indicate that neural systems mediating the receptivity are different from those mediating the proceptivity of sexual behavior. Therefore, changes in lor- 
dosis behavior may be associated with changes in hypothalamic LHRH level. In STZ-induced diabetic male rats, reductions in LHRH content lead to reductions in copulatory behavior [11].

In conclusion, results in the present experiments are the first to show that STZ-induced diabetic female rats have a decreased sexual receptive behavior similarly to male rats.

The authors wish to express their hearty to Associate Professor Dr. K. Nakama, Division of Laboratory Animal Science, Nippon Medical School, Bunkyo-ku, Tokyo 113, for his valuable advice and suggestion on this study. We also pleased to acknowledge the considerable assistance of $\mathrm{Mr}$. Y. Ogikubo, Department of Laboratory Animal Science, Nippon Veterinary and Animal Science University, Musashino-shi, Tokyo 180, Japan. This research was supported in part by grants-in-aid from Ministry of Education, Science and Culture of Japan (No. 05680742) to T. R. S.

\section{References}

[1] Dudley, C. A., Vale, W., River, J., and Moss, L.
(1981), Peptides, 2, 393-396.

[2] Howland, B. E. and Zebrowski, E. J. (1976). Horm. Metab. Res., 8, 465-470.

[ 3 ] Howland, B. E. and Zebrowski, E. J. (1980). Exper. ientia, 36, 610-613.

[4] Jensen, S. B. (1981). Arch. Sex. Behav., 10, 493504 .

[5] Jensen, S. B. (1986). Arch. Sex. Behav., 15, 271283.

[6] Kolodny, R. C. (1971). Diabetes, 20, 557-559.

[ 7 ] Saito, T. R. and Moltz, H. (1986). Physiol. Behav., 38, 81-87.

[8] Saito, T. R., Kamata, K., Nakamura, M., and Inaba, M. (1989). Jpn. J. Vet. Sci., 51, 191-193.

[9] Schreiner-Engel, P., Schiavi, R. C., Vietorisz, D., and Smith, H. (1987). J. Psychosom. Res., 31, 23-33.

[10] Steger, R. W., Amador, A., Lam, E., Rathert, J., Weis, J., and Smith, M. S. (1989). Endocrinology, $124,1,737-1,743$.

[11] Steger, R. W. and Kienast, S. G. (1990). Diabetes, 39, 942-948.

[12] Tattersall, R. (1982). Br. Med. J ., 285, 911-912.

[13] Tyrer, G, Steel, J. M., Ewing, D. J., Bancroft, J., Warner, P., and Clarke, B. F. (1983). Diabetologia, 24, $166-171$.

\title{
Streptozotocin (STZ) 誘発糖尿病雌ラットにおける性行動
}

\author{
斎藤徹・芹沢功**・外尾亮治*** ・ 藤平篤志 \\ 小守 涊**高橋和 明 \\ 日本獣医畜産大学実験動物学教室 \\ *日本獸医畜産大学附属家畜病院 \\ **キリンビール株式会社医薬開発研究所 \\ ***財団法人動物繁殖研究所土浦第 2 研究所
}

糖尿病男性の性機能障害については良く知られてい るが, 女性に関しては現在のところ明確な回答が得ら れていない。最近, streptozotocin 誘発糖尿病雄ラッ トに交尾行動の障害が認められている。今回, strept- ozotocin 誘発糖尿病雌ラットの性行動について検討し た結果，雄と同様にロードシス行動の抑制が観察され た。 